\title{
Reduction of the wage share of income and increasingly precarious employment
}

\author{
Daniel Velázquez Orihuela ${ }^{1}$
}

\begin{abstract}
"Keep workers insecure and keep them under control, and they're not going to ask for decent wages or decent working conditions, or the right of free association, meaning unionizing. Now for the masters of mankind that's fine. They make their profits. But for the population it's devastasting." (Requiem for the American Dream, 2015).
\end{abstract}

\begin{abstract}
The economic globalization that began in the late 1970s and early 1980s has generated job insecurity for workers. This coincides with two trends: a reduction in the wage share of income and increasingly precarious employment, both of which have been seen in most market economies since the early 1980s. This article proposes an efficiency-wage model in a demand-constrained equilibrium scenario, to explain how rising job insecurity has reduced the wage share of income and made employment more precarious. An additional virtue of this model is that it explains several features of the Mexican labour market observed in recent decades.
\end{abstract}

\section{Keywords}

Employment, labour market, wages, conditions of employment, labour relations, income, income distribution, econometric models, Mexico

\section{JEL classification}

D33, E24, E25

\section{Author}

Daniel Velázquez Orihuela is full-time Research Professor of Economics at the Autonomous University of the State of Hidalgo, Mexico. Email: daniel_velazquez7607@ uaeh.edu.mx. 


\section{Introduction}

A salient feature of the globalization of production, which began in the late 1970s and early 1980s, has been the relocation of production by transnational corporations to reduce labour costs. This has allowed such firms to undertake their labour-intensive processes in countries that have low wages and permissive labour regulations. The threat that production could be offshored has generated a state of insecurity among workers and has diminished their unions' bargaining power (Kalleberg, 2009). In addition, the collapse of the socialist bloc released millions of people on to the global labour market. Faced with this excess labour force, many of the world's poor countries have opted to compete for foreign direct investment (FDI) by offering low wages and flexible, or non-existent, labour regulations that allow and facilitate costless dismissal, which has generated a sense of job insecurity (Requiem for the American Dream, 2015). The perception of job insecurity among workers is one of the main effects that the globalization of production has had on labour markets, and is currently one of their key features in most cases (Kalleberg, 2009).

Production globalization, and the job insecurity it has generated, coincide with two major trends: a reduction in the wage share of income and the increasing precariousness of employment. Both of these started at the same time as globalization.

The shrinking wage share of income and increasing precariousness of employment are two trends that have been observed in rich and poor countries alike (IMF, 2007; ILO/OECD, 2015; Kalleberg, 2009). However, emerging and developing countries have experienced a more pronounced and steeper reduction in the share of wages in national income (ILO, 2011; Stockhammer, 2009) and a faster growth of precarious employment (Vázquez, Macias and Lawson, 2018) than has been the case in the rich countries.

According to ILO (2018), 46\% of workers in emerging economies and $76 \%$ of those in poor countries are in vulnerable forms of employment. As a counterpart of this phenomenon, in Asia, the wage share of national income has decreased by more than 20 percentage points since 1994, and in North African countries, it has shrunk by over 30 percentage points since 2000.

In Latin America, while the decline has been more moderate, barely exceeding 10\% since 1993, it has also been gathering pace (ILO, 2011). Abeles, Amarante and Vega (2014) claim that the labour share of output is declining in most Latin American countries, even when the income of self-employed workers is considered. Alarco (2014, 2016 and 2017) posits a common history in most Latin American countries, in which the wage share in 1950-2012 completes two cycles: the first cycle peaks in the mid-1960s, before dropping to a floor in the mid-1980s. The second peaks in the mid-1990s and reaches the bottom of the cycle between 2004 and 2006. ${ }^{2}$ Nonetheless, the long-term trend of the wage share has been down: it was higher between 1950 and 1979 than in 1980-2014. In other words, wages gained their largest share when the import substitution industrialization model was more intense or when sociopolitical circumstances favoured workers; in contrast, the minimum levels occur after the debt crisis of 1980, when pro-market policies were in force.

This article aims to show that job insecurity is one of the causes of both the increasing precariousness of employment and the shrinking share of wages in income. To this end, an efficiency-wage model is constructed in a demand-constrained equilibrium scenario. This analytical framework is used to study the mechanisms through which heightened insecurity of employment causes jobs to become more precarious and the wage share of income to decline. The model has the additional virtue of reproducing and explaining some of the characteristics of the Mexican labour market.

\footnotetext{
2 During the first five years of this century, the personal distribution of income improved, even though the wage share of income
} declined. This may reflect an underestimation of the income of the wealthiest percentiles (Abeles, Amarante and Vega, 2014). 
The article is divided into five sections, of which section II, following this introduction, identifies some of the characteristics of the Mexican labour market. Section III constructs an efficiency-wage model in a demand-constrained equilibrium scenario to provide a common explanation for the income concentration, increasingly precarious employment and characteristics of the Mexican labour market discussed in the second section. Section IV presents a numerical example of the theoretical model; and the fifth and final section sets forth the conclusions of the study.

\section{Selected characteristics of the Mexican labour market}

In recent decades, income concentration and increasingly precarious employment have been permanent features of the Mexican economy, and have been accompanied by the following trends:

(i) Although the labour share of national income has been shrinking ever since 1976, the decline has gathered pace in the last decade (Ros, 2015; Samaniego, 2014; Luyano and Herrera, 2018).

(ii) Since 2008, wages have converged downward, with the median of high wage segments falling faster than that of the lower segments. This has narrowed the wage gap between different worker categories, whether classified by their occupational position, by years of schooling, or by whether they work in the formal or the informal sector of the economy (Colmex, 2018).

The following developments have occurred in the last two decades:

(iii) The number of low-paying jobs has increased, while the number of high-paying jobs has declined. ${ }^{3}$

(iv) Precarious jobs (defined as those that lack access to social security, offer only a temporary contract or none at all, and where pay is equal to or less than a minimum wage) have increased (Colmex, 2018).

(v) While the average growth rate of labour productivity has slowed, the productivity of the tradable goods manufacturing sector has surged (Ros, 2013 and 2015).

To provide an explanation for these trends, the next section develops an efficiency-wage model in demand-constrained equilibrium scenarios, with special emphasis on the processes that drive income concentration and make employment more precarious. It is important to clarify that the model identifies precarious employment on the basis of three characteristics: lower wages, greater effort made by workers and heightened job insecurity. ${ }^{4}$

\section{The model}

\section{Initial conditions}

The starting point is an economy consisting of a large number of producers and consumers. The latter can be classified in two social classes. However, all members of each class have the same set of tastes and preferences; and, similarly, all firms have the same production function. This makes it possible to work with a single representative firm and one representative consumer for each social class.

\footnotetext{
3 As an example of the above: (i) in 2008 there were 1.5 million more workers earning over three times the minimum wage than in 2014; and (ii) the percentage of employees (paid subordinate workers) being paid less than the minimum wage increased from $14.4 \%$ in 2000 to $24.0 \%$ in 2017 (Samaniego, 2014; Colmex, 2018).

4 There is no consensus on all of the characteristics needed to identify the "precarious work" category. In most of the specialized literature, however, they include low wages, job insecurity and the intensity or length of the working day.
} 
Social classes are distinguished by two characteristics: (i) their income source; and (ii) their tastes and preferences. Distinguishing social classes by their income source is typical of both classical and Marxist theory. Workers whose sole source of income is their labour, which is employed and paid for by firms, are called proletarians; and the owners of capital, whose main source of income is the profits of the enterprises they own, are called capitalists. Following this tradition, this article will also refer to the two social classes as "proletariat" and "capitalist". In addition to the difference based on income source, it is assumed that capitalists employ labour to increase their leisure or make it more enjoyable.

In this model, proletarians have two work alternatives: the first is in firms (referred to as conventional employment); and the second is self-employment. Self-employed workers do not have the capital or the organization to set up a formal enterprise, so they supply their labour services to capitalist consumers, to increase the latter's leisure or make it more enjoyable. The only income that self-employed workers receive is the wage paid to them by capitalist consumers. This means that there are two production sectors: a conventional sector, in which firms produce goods, and another sector in which the self-employed supply their services.

Information is asymmetric and imperfect, so neither firms nor capitalist consumers can identify which of their workers are exerting themselves and which are not. It will be assumed that worker effort increases as wages or the subjective probability of dismissal increases. As a result all employers pay an efficiency wage, i.e., they pay the wage that maximizes their rate of profit or utility, as applicable.

The positive relations that exist between wages and effort and between the probability of dismissal and effort are standard assumptions in efficiency-wage theory (Caraballo, 1996). The probability of dismissal is usually represented by the unemployment rate. However, this study assumes that the subjective probability of dismissal reflects the workers' perception of job insecurity, which, in addition to the unemployment rate, takes into account variables such as the existence and duration of the employment contract, the existence of social security, the flexibility of labour legislation and respect for labour rights, among other issues. ${ }^{5}$ Consequently, this perceived likelihood of dismissal can increase even without a rise in the unemployment rate.

The self-employed have less job stability, in other words they can be dismissed more easily than workers employed in firms. This idea is supported by the fact that the self-employed usually lack unions, social security, written contracts and legal protection. In this regard, Mexico's National Institute of Statistics and Geography (INEGI) shows that less than 1\% of self-employed workers in the Mexican economy have some form of social security (INEGl, 2017).

The subjective probability of dismissal among the self-employed $\left(p_{b}\right)$ depends positively on the subjective probability of dismissal among conventional workers $\left(p_{a}\right)$. This hypothesis is supported by the fact that when unemployment rises, the unemployed may turn to self-employment. This will increase the supply of services provided by the self-employed and make finding employment harder for all of them. In this regard, Ros (2013) recognizes that the low-productivity service sector has become the last stage through which Mexican workers move before falling into unemployment.

The ideas expressed in the previous two paragraphs are formalized in the following hypotheses: $0<p_{a}<p_{b}<1$ and $0<\frac{d p_{b}}{d p_{a}}<1$.

\footnotetext{
5 According to Corporación Latinobarómetro (2005), 75\% of workers in Latin America were afraid of losing their jobs in the next 12 months, and this percentage rose to $82 \%$ in the case of Mexican workers.
} 


\section{Representative firm}

The firm's optimizing behaviour is formalized through the following maximization exercise:

$$
\max (1+\pi)=\frac{y_{0}}{w l_{a}}
$$

Subject to

$$
y_{0}=A f\left(e\left(w, p_{a}\right) l_{a}\right)
$$

In expressions (1) and (2), $(1+\pi)$ is the rate of profit, $y_{0}$ is the supply of output, $w$ is the real wage, $l_{a}$ is the firm's demand for labour, $e\left(w, p_{a}\right)$ is the effort function and $p_{a}$ is the subjective probability of being fired by the firm.

Where $A \in \Re^{+}, e_{w}^{\prime}>0, e_{w}^{\prime \prime}<0, e_{p_{a}}^{\prime}>0, e_{p_{a}}^{\prime \prime}<0, e_{w, p_{a}}^{\prime \prime}=0, e(w, 0)>0,0<p_{a}<1$ and $f$ is a homogeneous function of degree 1.

The formalization of the firm's rationality axiom has two key features:

(i) Firms aim to maximize their profit rate, which is defined as the quotient of sales revenue over costs. This differs from standard neoclassical theory, which postulates that firms maximize the absolute level of profit (the difference between sales and costs). However, it is consistent with the classical and Marxist idea that the main variable guiding firms' decisions is the profit rate. More recently, financial investment theory highlights different rates of return as the key variables used by investors in deciding where to invest.

(ii) Following Solow (1979), from the standpoint of the individual firm, the wage has two characteristics: firstly, it is part of labour costs; and, secondly, it stimulates worker effort. Consequently, firms pay the wage that elicits the greatest effort from the worker at the lowest possible cost, and enables them to maximize their profit rate.

Solving the maximization exercise (equations (1) and (2) ${ }^{6}$ gives:

$$
\begin{gathered}
\frac{e_{w}^{\prime}}{e\left(w, p_{a}\right)} w=1 \\
A f_{l_{a}^{\prime}}^{\prime}=\frac{A f\left(e\left(w, p_{a}\right) l_{a}\right)}{l_{a}}
\end{gathered}
$$

Equation (3) is the Solow equation, which ways that producers maximize profit when the wage they pay ensures that the elasticity of effort with respect to the wage is unity. The wage that satisfies this condition for the firms is called the efficiency wage $\left(w^{a}\right)$.

Equation (4) is a condition that is usually obtained in analytical frameworks that involve maximization of the profit rate. It shows that firms maximize when the average and marginal products of labour are equal (Noriega, 2001; Velázquez and Hernández, 2018; Velázquez, Vargas and Hernández, 2019).

Note that equation (3) implies that producers set the wage independently of labour supply and demand, so there is no guarantee that the efficiency wage elicits full employment. On the other hand, because the production function is homogeneous of degree 1, equation (4) holds for all positive labour demand; and the optimal rate of profit is independent of the level of employment, but does depend on the wage:

6 See section 1 of annex A1. 


$$
\max (1+\pi)=\frac{A e\left(w^{a}, p_{a}\right)}{w^{a}}
$$

Unlike the profit rate, the absolute level of profit does depend on the level of employment. As long as firms offer the efficiency wage, absolute profit will be:

$$
\Pi=\left(A e\left(w^{a}, p_{a}\right)-w^{a}\right) l_{a}
$$

Note that the Solow condition implies that the efficiency wage is: $w^{a}=\frac{e\left(w^{a}, p_{a}\right)}{e_{w}^{\prime}}$. So, as long as $A>\frac{1}{e_{w}^{\prime}}$ the profit rate will be positive, and absolute profit will grow as employment increases, so that: $\frac{d \Pi^{w}}{d l_{a}}=A e\left(w^{a}, p_{a}\right)-w^{a}>0, \frac{d^{2} \Pi}{d l_{a}^{2}}=0$ and $\lim _{l_{a} \rightarrow \infty} \Pi=\infty$. This does not mean that the level of employment is unknowable, or that full employment is maintained systematically. Firms will produce only what the market demands, because if they produce more they will accumulate unwanted inventories and, hence, make losses. Consequently, they adjust their production to the prevailing effective demand, and this determines the maximum amount of labour to be hired $\left(\hat{y}_{d}\right)$. However, as will be shown in part 5 of this section, there is no market mechanism that systematically guarantees a level of effective demand that is compatible with full employment.

From the above, it follows that:

$$
\begin{gathered}
\hat{y}_{d}=A e\left(w^{a}, p_{a}\right) l_{a} \\
l_{d}=\frac{\hat{y}_{d}}{A e\left(w^{a}, p_{a}\right)}
\end{gathered}
$$

Equation (7) simply shows that production adjusts to the prevailing effective demand, as a condition for obtaining the maximum possible profit; equation (8) expresses firms' labour demand. This is analogous to the employment function proposed by Keynes (1936), since, like the latter, it shows that the level of employment depends positively on effective demand.

\section{Proletarian consumer}

The proletarian consumer's rational behaviour is formalized through the following maximization exercise:

$$
\max U^{p}=\alpha \ln c^{p}+(1-\alpha) \ln \left(\tau^{p}-e\left(w, p_{i}\right) l_{0}\right)
$$

Subject to

$$
w l_{0}=c^{p}
$$

In expressions (9) and (10), $p_{i}$ (for all $i=a, b$ ) is the subjective probability of being fired in the case of persons employed in firm ( $i=a)$ or in the case of the self-employed $(i=b) ; 0<\alpha<1 ; c$ is consumer demand, $\tau$ is the time that is biologically available for work; and $l_{0}$ is the labour supply of a conventional worker or a self-employed person, as the case may be. The superscript $p$ refers to the representative consumer of the proletarian class. Key aspects of the formalization of the rational behaviour of the proletarian consumer include the following: 
(i) Utility is modelled as a Cobb-Douglas function; it is therefore well-behaved.

(ii) Proletarian consumers supply efficient labour $\left(e\left(w, p_{i}\right) l_{0}\right)$. Thus, an increase in their effort, ceteris paribus, will reduce their utility.

The maximization exercise gives the demand for consumption and the supply of labour, as follows:

$$
\begin{gathered}
c^{p}=\frac{\alpha \tau^{p} w}{e\left(w, p_{i}\right)} \\
l_{0}=\frac{\alpha \tau^{p}}{e\left(w, p_{i}\right)}
\end{gathered}
$$

Equations (11) and (12) represent habitual purchase and sale plans. Note that labour supply is not constant, but varies as worker effort changes.

\section{Capitalist consumer}

The rational maximizing behaviour of the representative capitalist consumer is formalized as follows:

Subject to

$$
\max U^{c}=\beta \ln c^{c}+(1-\beta) \ln \left(e\left(w, p_{b}\right) l_{b}\right)
$$

In expressions (13) and (14), $0<\beta<1$; the superscript $c$ refers to the representative consumer of the capitalist class; and $l_{b}$ is the capitalist consumer's demand for labour.

Formalization of the capitalist consumer rationality axiom has four key features:

(i) Similarly to the proletarian consumer's utility function, the capitalist consumer's utility is also modelled as a Cobb-Douglas function.

(ii) The idea that capitalist consumers' only source of income is the profit received from the enterprises they own implies that capitalist consumers do not supply labour. This is why labour supply appears neither in their utility function nor in their budget constraint.

(iii) The hypothesis that capitalist consumers demand labour to increase their leisure or make it more enjoyable is formalized by introducing their demand for labour multiplied by effort in their utility function.

(iv) Both capitalist consumers and firms know that workers' effort depends on the wage paid to them; so they offer a wage that elicits maximum worker effort and minimizes labour cost.

The maximization exercise gives the demands of the capitalist consumers and the wage that maximizes their utility:

$$
\begin{gathered}
l_{b}=(1-\beta) \frac{\Pi}{w} \\
c^{c}=\beta \Pi \\
\frac{e_{w}^{\prime}}{e\left(w, p_{b}\right)} w=1
\end{gathered}
$$


Equation (15) represents the capitalist consumer's demand for labour, in other words the demand for labour supplied by the self-employed. It depends positively on profit and negatively on the wage. Equation (16) represents consumption demand and simply shows that capitalists consume a proportion of their profit. Equation (17) is the Solow equation, which states that capitalist consumers maximize their utility when they pay a wage that ensures that the elasticity of effort relative to the wage is equal to 1 ; in other words when they pay efficiency wages $\left(w^{b}\right)$. However, the efficiency wage paid by firms $\left(w^{a}\right)$ does not necessarily have to be equal to the wage offered by capitalist consumers $\left(w^{b}\right)$. This is because the self-employed and workers employed by firms have different subjective probabilities of being fired.

Comparing the wages offered by the firms with those received by the self-employed, it follows that, as $P_{a}<p_{b}$ then $w^{b}<w^{a}$. In other words, self-employed earnings are lower than the wages offered by firms, because the self-employed have a higher subjective probability of being fired. The reason for this is that the greater perception of job insecurity among the self-employed forces them to exert more effort than conventional workers to avoid unemployment; consequently, capitalist consumers can pay lower wages than firms and still extract the same effort from their workers.

\section{Demand-constrained general equilibrium}

The demand-constrained equilibrium is represented by the price and allocation vectors observed when output systematically adjusts to effective demand. However, the latter is not large enough to guarantee full employment. In the literature, demand-constrained equilibrium is usually explained in terms of prices being slow to adjust, which causes agents to engage in out-of-equilibrium transactions (Argandoña, Gámez and Mochón, 1996). In contrast to that literature, but analogous to Velázquez and Hernández (2018), this paper posits that demand-constrained equilibrium arises because firms' labour hiring plans are not inversely related to the real wage (see equation 8), and because wages are independent of labour supply and demand (see equations (3) and (17)).

The goods and labour markets are represented by the following equations:

$$
\begin{gathered}
\hat{y}_{d}-y_{0}=0 \\
l_{a}-\phi l_{0}=0 \\
l_{b}-(1-\phi) \gamma l_{0}=0
\end{gathered}
$$

Equation (18) represents the market for goods; effective demand $\left(\hat{y}_{d}\right)$ is the sum of all demands that can be financed, that is, the consumption plans that agents can afford with the profits they receive from firms or with the remuneration they obtain by offering their labour services and being employed. Equation (19) represents the "conventional" labour market, which links firms' demand for labour with what workers' supply; $\phi$ is the proportion of labour supply that is employed in this market, where $\phi \in(0.1)$. Equation (20) represents the self-employed labour market, which links the demand for labour by capitalist consumers to the labour supplied by the self-employed; $\gamma$ is the percentage of labour employed in this market; consequently, $(1-\gamma)(1-\phi)$ is the unemployment rate. ${ }^{7}$ Hereinafter equation (19) will be referred to as the "conventional labour market" and equation (20) as the "self-employment labour market".

\footnotetext{
7 The labour supply hired by firms is $\phi l_{0}$ and the labour supply contracted by capitalist consumers is $(1-\phi) \gamma l_{0}$. Consequently, the unemployed labour force is $(1-\phi)(1-\gamma) l_{0}$ and the unemployment rate is $(1-\phi)(1-\gamma)$.
} 
Wages in the conventional and self-employment labour markets are determined by equations (3) and (17), respectively. Henceforth, it is assumed that the wages paid in these markets are efficiency wages.

Effective demand comprises the sum of the financiable demands of the capitalist consumer and those of the proletarian consumer. Considering equations (11) and (16), gives:

$$
\hat{y}_{d}=\beta \Pi+\phi \frac{\alpha \tau^{p} w^{a}}{e\left(w^{a}, p_{a}\right)}+(1-\phi) \frac{\alpha \tau^{p} w^{b}}{e\left(w^{b}, p_{b}\right)} \gamma
$$

The first term on the right side of equation (21) is the financeable demand of the capitalist consumer; the second and third terms are the demand that the proletarian consumer can afford with the supply of labour that is employed and remunerated in the conventional labour and self-employment markets, respectively. Solving for equilibrium in the goods market, gives: ${ }^{8}$

$$
A e\left(w^{a}, p_{a}\right) l_{a}-\phi \frac{\alpha \tau^{p} w^{a}}{e\left(w^{a}, p_{a}\right)}+\phi \frac{\alpha \tau^{p} w^{a}}{e\left(w^{a}, p_{a}\right)}-A e\left(w^{a}, p_{a}\right) l_{a}=0
$$

Equation (22) shows that demand-constrained equilibrium is guaranteed in the goods market irrespective of the values of $\phi$ and $\gamma$. That is, whatever the distribution of employment across markets and whatever the unemployment rate, output will adjust to effective demand.

Note that it is impossible to determine the value of $\phi$ without assuming that the effective demand (equation (8)) or the level of employment used by the firms is known. However, assuming the value of $\phi$ is known, then $\gamma$ can be determined as:

$$
\gamma=\frac{\phi(1-\beta)}{(1-\phi)} \frac{w^{a}}{e\left(w^{b}, p_{b}\right)}\left(1-\frac{w^{a}}{e\left(w^{a}, p_{a}\right)}\right)
$$

Expression (23) makes it clear that there are no market mechanisms guaranteeing that $\gamma$ is equal to 1 , in other words that full employment is achieved. This is because nothing ensures that effective demand is sufficient to elicit full employment. This result differs from what is usually obtained in efficiency-wage models; for example, in Shapiro and Stiglitz (1984), equilibrium occurs with unemployment because the latter is needed to extract a positive effort from workers. In contrast, in this analytical approach effort is positive, even is the subjective dismissal rate is 0 .

\section{Initial conditions for the analysis of job insecurity and the income distribution}

The increasingly precarious nature of employment is a dynamic process that entails a drop in wages, greater insecurity in terms of being employed and an increase in the effort made by workers. The analysis of how more precarious employment leads to a higher concentration of income, starts from a demand-constrained equilibrium and introduces Clower's (1965) dual decision hypothesis, whereby all agents are both buyers and sellers, in that to be able to buy they must first have sold. This means that effective demand depends on the labour that the proletarian consumer managed to sell and on the profits that firms obtained from their sales, in both cases in the past period. Incorporating this hypothesis, gives: ${ }^{9}$

\footnotetext{
8 See section 2 of annex A1.

9 See section 2 of annex A1.
} 


$$
\hat{y}_{d}=l_{a-1} w^{a}+\Pi_{-1}
$$

In equation (24) the subscript - 1 means the variable in question is of the previous period, so it can be considered fixed. The effective demand expressed in equation (24) has two characteristics: (i) the wage does not carry the subscript because it is a current variable. This is because workers work for a period (such as a week or a fortnight), at the end of which they receive their wages, which they then use to finance their consumption in the next period; (ii) the consumption of the self-employed does not appear as part of effective demand. This is because capitalists finance their demand for both goods and labour with the profits they receive from firms; consequently, profits incorporate the consumption demand of both self-employed workers and capitalists.

\section{Increasingly precarious employment}

The analysis of the increasingly precarious nature of employment assumes that conventional jobs become less secure, so the perceived probability of dismissal among workers employed in firms rises. Consequently, conventional workers exert more effort to avoid being caught slacking and being fired as a result. The increased effort motivates firms to reduce wages, because high wages are no longer required to elicit effort. Thus, equation (3) gives:

$$
\frac{d w^{a}}{d p_{a}}=\frac{e_{p_{a}}^{\prime}}{e_{w}^{\prime \prime} w^{a}}<0
$$

Greater insecurity in conventional employment increases insecurity in self-employment, because, as noted above, workers who lose their jobs in firms will seek self-employment, which makes it harder for all self-employed workers to obtain work. Thus, $0<\frac{d p_{b}}{d p_{a}}<1$.

Analogously to what happens with conventional workers, the increase in the subjective probability of dismissal among self-employed workers causes them to exert more effort to avoid unemployment. The greater effort motivates capitalist consumers to pay lower wages, since their workers are already exerting themselves. Thus, equation (17) gives:

$$
\frac{d w^{b}}{d p_{a}}=\frac{e_{p_{b}}^{\prime}}{e_{w}^{\prime \prime} w^{b}} \frac{d p_{b}}{d p_{a}}<0
$$

Expressions (25) and (26) show that wages among workers employed in firms and among those who are self-employed both decrease. This then causes a reduction in effective demand. Equation (24) gives:

$$
\frac{d \hat{y}_{d}}{d p_{a}}=l_{1-1} w_{p_{a}}^{a,}<0
$$

Equation (27) shows that effective demand decreases because the purchasing power of workers employed in firms declines. However, lower incomes among the self-employed do not affect effective demand. This is because a reduction in the consumption of self-employed workers will be compensated by an increase in consumption by capitalists, since the latter use their profits to pay the workers they employ. Thus, consumption by both categories of consumer is ultimately financed by profits.

The reduction in effective demand forces firms to adjust their production downwards; so, they need to hire fewer workers. Equation (8) gives: 


$$
\frac{d l_{a}}{d p_{a}}=\frac{1}{A}\left[\frac{\hat{y}_{d, p_{a}}^{\prime} e\left(w^{a}, p_{a}\right)-\left(e_{w^{a}}^{\prime} w_{p_{a}}^{a,}+e_{p_{a}}^{\prime}\right) \hat{y}_{d}}{e\left(w^{a}, p_{a}\right)^{2}}\right]<0
$$

Inequality (28) shows that there are two reasons why firms' demand for labour decreases: (i) the increase in effort made by each worker $\left(e_{w^{a}}^{\prime} w_{p_{a}}^{a,}+p_{a} e_{p_{a}}^{\prime}\right)$; and (ii) the decrease in effective demand $\left(\hat{y}_{d, p_{a}}^{\prime}\right)$. These results imply two key features:

(i) The change in workers' effort stems from two opposing effects. First, heightened job insecurity motivates workers to make a greater effort to avoid unemployment; and second, the greater effort they make allows firms to pay lower wages, which then discourages workers, causing them to reduce their effort. It is impossible a priori to determine which force will dominate. This article postulates that when faced with an increase in the subjective probability of dismissal, workers increase their effort, despite the reduction in wages. This is true as long as $e_{p_{a}}^{\prime}>\left|e_{w^{a}}^{\prime} w_{p_{a}}^{a}\right|$, which obtains provided that $\left|e_{w}^{\prime \prime} w^{a}\right|>\left|e_{w}^{\prime}\right|$.

(ii) The reason why less effective demand reduces the level of employment is that firms adjust their production downward to match the lower effective demand, thus requiring less labour.

Since entrepreneurs adjust their production to the currently prevailing effective demand, equation (18) gives:

$$
\frac{d y_{0}}{d p_{a}}=\frac{d \hat{y}_{d}}{d p_{a}}
$$

Equation (29) shows that output decreases by the same amount as effective demand. The decrease in both output and labour costs and the increase in effort change profits. This can be analysed by obtaining their differential with respect to the subjective probability of dismissal:

$$
\frac{d \Pi}{d p_{a}}=\left[A\left(e_{w^{a}}^{\prime} w_{p_{a}}^{a,}+e_{p_{a}}^{\prime}\right)-w_{p_{a}}^{a}\right] l_{a}+\left[A e\left(w^{a}, p_{a}\right)-w^{a}\right] l_{a, p_{a}}^{\prime}>0
$$

Equation (30) indicates that the reduction in labour costs and the increase in workers' effort both generate higher profit, even though the lower level of employment reduces output and, thus, puts downward pressure on profit. ${ }^{10}$ In other words, profit grows because the gap between labour productivity and wages widens, despite the drop in sales. Thus, under this scenario, the increase in profit changes the factor distribution of income in favour of capitalists.

The additional profit allows capitalist consumers to demand more consumer goods and more services supplied by the self-employed. Equations (15) and (16) give:

$$
\begin{gathered}
\frac{d l_{b}}{d p_{a}}=(1-\beta) \frac{\Pi^{\prime}}{w^{b}}-(1-\beta) \frac{\Pi}{w^{b^{2}}} w_{p_{a}}^{b,}>0 \\
\frac{d c^{c}}{d p_{a}}=\beta \Pi^{\prime}>0
\end{gathered}
$$

Expression (31) shows that capitalist consumers demand more labour because the price of labour has fallen, and their income has risen. Consequently, the employment of self-employed workers expands.

10 See section 3 of annex $A 1$. 
Moreover, inequality (32) shows that capitalists consume more goods when their income increases. Note that the fall in production and the growth of capitalist consumption imply that proletarian consumption declines, despite the increase in self-employment; in contrast, capitalists' consumption of both goods and services increases. This is a consequence of the growth of profits, the decrease in wages received by both conventional and self-employed workers, and the reduction in conventional employment.

\section{Analysis of selected characteristics of the Mexican labour market}

\section{(a) Concentration of income}

The first characteristic to analyse is the reduction in the workers' share of national income. In this model, national income is composed of the value of goods production $\left(y_{0}\right)$ plus the value of the services $\left(w^{b} l_{b}\right)$ services provided by workers to capitalist consumers. Consequently, the shares of profits and wages in national income $(I N)$ are defined, respectively, by:

and

$$
\frac{\Pi}{I N}=\frac{\Pi}{y_{0}+w^{b} l_{b}}
$$

Note that equation (15) implies that $w^{b} l_{b}=(1-\beta) \Pi$. Hence:

$$
\frac{d \frac{\Pi}{I N}}{d p_{a}}=\frac{\Pi_{p_{a}}^{\prime}\left(y_{0}+(1-\beta) \Pi\right)-\Pi\left(y_{0, p_{a}}^{\prime}+(1-\beta) \Pi_{p_{a}}^{\prime}\right)}{\left(y_{0}+w^{b} l_{b}\right)^{2}}>0
$$

Equation (35) states that the profit share of national income rises, so the wage share falls. This happens because the profits outpace the growth of national income, since the fall in goods production is not sufficiently compensated by an increase in services to allow national income to grow by more than profits.

The concentration of income in favour of profits means that the wage share of income declines, owing to the reduction in wages, the growth of more precarious employment (self-employment) and the reduction of conventional employment.

\section{(b) Downward wage convergence}

The second characteristic to analyse is downward wage convergence. According to equations (25) and (26), the wages of both conventional and self-employed workers decreased. However, downward wage convergence requires the wages of conventional workers to decrease by more than those of the self-employed. This only happens if $\frac{w^{b}}{w^{a}}>\frac{d p_{b}}{d p_{a}}$, that is, if $\frac{d p_{a}}{d p_{b}}>\frac{w^{a}}{w^{b}}$. In other words, the difference between the increase in insecurity among conventional employees and the increase among the self-employed must exceed the wage gap. 


\section{(c) Growth of precarious work and decrease in well-paid employment}

The third and fourth characteristics of the Mexican labour market to be analysed are the facts that precarious employment expanded, while non-precarious employment declined. In terms of the model presented here, this means that employment that is lower paid, more insecure and requires greater effort, in other words self-employment, grew; in contrast, conventional employment decreased, which is consistent with inequalities (28) and (31).

Conventional employment declines because the effective demand satisfied by firms is reduced owing to the lower wages received by conventional workers; in contrast, self-employment expands because higher profits and the lower wages of the self-employed allow capitalists to increase their demand for services.

\section{(d) Manufacturing productivity grows faster than average}

The final characteristic of Mexico's labour market to be analysed is the fact that the average productivity of tradable manufactured goods outpaces average total productivity. This means that there is a production sector in which productivity growth is above average. To analyse this phenomenon, note that the average productivity of the conventional sector is $\frac{y_{0}}{l_{a}}=\frac{e\left(w^{a}, p_{a}\right) A l_{a}}{l_{a}}$ by definition, whereas the average productivity of the services offered by the self-employed is defined as $\frac{w^{b} l_{b}}{l_{b}}$. Neither of the two productivities depends on the level of employment, since both are homogeneous of degree 0 in employment. However, they respond in opposite ways to the increase in job insecurity.

Productivity in the conventional sector increases in response to an increase in the subjective probability of dismissal. This is because if workers perceive a higher probability of dismissal, they work harder and are therefore more productive. This can be represented in the following equation:

$$
\frac{d \frac{y_{0}}{l_{a}}}{d p_{a}}=A\left[e_{p_{a}}^{\prime}+e_{w}^{\prime} w_{p_{a}}^{a^{\prime}}\right]>0
$$

In contrast, the average productivity of the services offered by the self-employed is reduced in the face of greater job insecurity. The reason is that, similarly to what happens with conventional workers, if the subjective probability of dismissal increases, self-employed workers work harder; consequently, capitalist consumers can pay lower wages. Lower wages means the services supplied are valued less, so the average productivity of the sector decreases. Hence:

$$
\frac{d \frac{w^{b} l_{b}}{l_{b}}}{d p_{a}}=w_{p_{b}}^{b^{\prime}} p_{b, p_{a}}^{\prime}<0
$$

The reduction in the average productivity of services means that the average productivity of the economy as a whole grows more slowly than the average productivity of the conventional sector, which is consistent with the data available for Mexico.

The results presented thus far stands in contrast to post-Kaleckian theory, ${ }^{11}$ which studies the factor distribution of income and its effects on employment and output. The main differences and similarities include the following:

${ }^{11}$ It is not intended to make an exhaustive review of this literature here. See Hein (2014) for further details. 
(i) In these post-Kaleckian models, the wage share of output declined owing to an increase in mark-up and in the degree of monopoly, which could be caused by exchange rate depreciations (Bhaduri and Marglin, 1990), interest rate hikes (Hein, 2014) or exogenous cuts in real wages. Unlike these models, in the analytical approach presented here, the wage share of income declines without assuming monopolies in the goods market and, hence, overpricing. However, postulating efficiency wages assumes non-competitive labour markets, in which capitalist firms and consumers can set wages according to their interests. This is because proletarians have to work for a living. Consequently, an increase in job insecurity enhances employers' wage-setting power, which therefore causes the wage share of income to fall.

(ii) The models in question also have scenarios in which production is driven by wages or by profits. They recognize the dual nature of wages: as components of demand and as costs of production. Like these models, the analytical approach adopted in this article also recognizes the dual nature of wages; however, there are no mechanisms that translate higher enterprise profitability, sustained by a cut in wages, into effective demand growth, since neither investment nor net exports are studied - two issues that form part of the pending research agenda.

\section{Numerical exercise}

To give greater clarity to the theoretical model presented here, a numerical example is presented below, based on a parametrically defined effort function, analogous to the one proposed by Velázquez and Hernández (2018): $e\left(w, p_{i}\right)=1-\frac{a}{w}+p_{i}^{\delta}$ where $a \in \mathfrak{R}^{+}, 0<\delta<1$ and $0<p_{i}<1$ for all $i=a, b$.

The characteristics of this function are: 12

(i) $e_{w}^{\prime}>0 ; e_{w}^{\prime \prime}<0 ; e_{p_{i}}^{\prime}>0 ; e_{p_{i}}^{\prime \prime}<0$ and $e_{w, p_{i}}^{\prime \prime}=0$

(ii) $\quad e(w, 0)=1-\frac{a}{w}$

(iii) $\quad e(w, 1)=2-\frac{a}{w}$

(iv) $\quad \lim _{w \rightarrow 0} e\left(w, p_{i}\right)=-\infty$

(v) $\quad \lim _{w \rightarrow \infty} e\left(w, p_{i}\right)=1+p_{i}^{\delta}$

The characteristics of the effort function include the following: (i) effort will be positive whatever the subjective probability of dismissal. However, as agents expect this probability to rise, they will increase their effort; (ii) As the wage tends to 0 , workers will cease making effort. On the other hand, as the wage tends to infinity, effort is bounded.

The relationship between the subjective dismissal rate of the self-employed and that of conventional workers is determined by:

$$
p_{b}=\zeta+\varphi p_{a}
$$

where $0<\zeta<1 ; 0<\varphi<1$ and $0<p_{b}<p_{a}$.

Equation (38) shows that the subjective dismissal rate among the self-employed has one part that does not depend on what happens in the conventional sector $(\xi)$ and another that absorbs that sector's insecurity $(\varphi)$.

The production function will be $y_{0}=A e\left(w, p_{a}\right) l_{a}$. The utility functions will be those proposed in equations (8) and (12). The numerical values of the parameters of the functions are specified in table 1.

\footnotetext{
12 The main difference between the function proposed by Velázquez and Hernández (2018) and the one put forward in this paper is that, in the former, the authors assume that the subjective probability of dismissal can be represented by the expectation of unemployment.
} 
Table 1

Parameters of the functions of production, effort, subjective probability of self-employed dismissal and utility

\begin{tabular}{ccccccccc}
\hline $\mathrm{A}$ & $\mathrm{a}$ & $\delta$ & $p_{\mathrm{a}}$ & $\zeta$ & $\varphi$ & $\alpha$ & $\beta$ & $\tau^{p}$ \\
\hline 10 & 1 & 0.9 & 0.01 & 0.05 & 0.9 & 0.4 & 0.9 & 99 \\
\hline
\end{tabular}

Source: Prepared by the author.

Note: $\quad \mathrm{A}, \mathrm{a}$ and $\delta$ are parameters; the first pertains to the production function, the next two to the effort function. $\alpha$ and $\beta$ are the elasticities of utility with respect to consumption, of the proletarian consumer and the capitalist consumer, respectively (see the production, effort, and utility functions).

The numerical exercise is presented in two scenarios. In the first, a demand-constrained equilibrium is calculated, in which the percentage of labour supply employed in the firms $(\phi)$ is assumed known and exogenous. This assumption is dispensed with in the second case. This first scenario will serve as a starting point for analysing the precariousness of employment and the concentration of income. In the second scenario, it is assumed that the subjective probability of dismissal among conventional workers increases; this makes employment more precarious, concentrates income in favour of business owners, reduces the wage gap downwards, increases precarious employment, decreases conventional employment, and increases productivity in the conventional sector by more than average productivity.

\section{Scenario 1: demand-constrained equilibrium}

The parameters used in this scenario are the same as will be used in scenario 2 (see table 1).

The chosen parameters have the following features: the subjective probability of dismissal among conventional workers $\left(p_{a}\right)$ is $1 \%$. In other words, workers feel relatively secure in their jobs. This value is chosen so that it can be increased in the next scenario. The proletarians represent $99 \%$ of the population $\left(\tau^{p}\right)$. As the subjective probability of dismissal among conventional workers increases by 1.0 unit, that of the self-employed rises by 0.9 . In other words, job insecurity is highly transferable from one sector to the other $(\varphi)$. This assumption is made because, in the absence of unemployment insurance, workers laid off in the conventional sector will seek self-employment as a last resort to avoid unemployment. In addition to these parameters, formal employment is assumed to account for $80 \%$ of the labour supply, so $\phi=0.8$. This is consistent with the fact that the self-employed in Mexico represent about $20 \%$ of the total labour force (INEGI, 2017). These parameters are used to obtain the allocations shown in table 2.

Table 2

Wages, allocations, and distribution in demand-constrained equilibrium

\begin{tabular}{cccccccc}
\hline$p_{a}$ & $p_{b}$ & $w^{a}$ & $w^{b}$ & $e\left(w^{a}, p_{a}\right)$ & $e\left(w^{b}, p_{b}\right)$ & $I_{a}$ & $I_{b}$ \\
\hline 0.01 & 0.059 & 1.968 & 1.854 & 0.507 & 0.539 & 62.371 & 10.459 \\
\hline$I_{b} \%$ & $u$ & $y_{0}$ & $S_{a}$ & $I N$ & $c^{c}$ & $c^{p}$ & $\% c_{t}^{c}$ \\
\hline 14.361 & 5.489 & 316.8 & 19.4 & 336.2 & 174.602 & 142.197 & 57.704 \\
\hline$\% c_{t}^{p}$ & $\Pi \sigma$ & $M . S$ & $\%$ & $\% M . S$ & $P m e s$ & $P m e c$ & $P m e t$ \\
\hline 42.295 & 194.003 & 142.197 & 57.704 & 42.295 & 1.854 & 5.079 & 4.616 \\
\hline
\end{tabular}

Source: Prepared by the author.

Note: $\quad p, w, e(w, p)$ and / are the subjective probability of dismissal, real wage, effort and labour demand, respectively; subscript or superscript "a" refers to the conventional worker and "b" to the self-employed worker; $I_{b} \%$ is self-employment as a percentage of total employment; $u$ is the unemployment rate; $y_{0}$ is manufacturing output; $S_{a}$ is the value of services; IN is national income; $c^{c}, \% c^{c}, c^{p}$ and $\% c^{p}$ are consumption by capitalists, their share of total consumption, consumption by proletarians and their share of total consumption, respectively; $\Pi$ is the profit received by the capitalists from the enterprises they own; M.S. is the wage bill; \% $\%$ represents the profit share of national income; \%M.S. is the share of wages in national income; Pmes, Pmec and Pmet represent average productivity in the service sector, the conventional sector and total, respectively. 
Table 2 shows the wages and allocations of the demand-constrained equilibrium. Workers employed by firms earn wages above those received by the self-employed. However, the latter make more effort, because their jobs are less secure, and they work harder to avoid dismissal. This, in turn encourages their employers to pay lower wages. Self-employed workers represent $14.361 \%$ of total employment. Note that this is less than the share of self-employed workers in the total labour force $(\phi=0.2)$ because not all labour is employed. The unemployment rate $(u)$ is $5.48 \%$. The sum of the consumption of goods by workers and by capitalists equals the value of goods production, since firms adjust their production to what the market demands. National income $(N I)$ is the sum of the value of goods produced by firms and the value of services provided by the self-employed $\left(S_{a}\right)$. Consumption by capitalists, of both goods and services $\left(c_{t}^{c}\right)$, absorbs $57.704 \%$ of national income, while the remaining $42.295 \%$ corresponds to consumption by the proletariat. As would be expected, these percentages coincide with the functional distribution of income. Lastly, it can be seen that the average productivity of the conventional sector (Pmec) is higher than that of the self-employed services sector (Pmes). Average total productivity $(P m e t)$ is therefore lower than that of the conventional sector.

\section{Scenario 2: increasing precariousness and income concentration caused by heightened job insecurity}

In this scenario it is assumed that the subjective probability of dismissal among conventional workers rises steadily; in other words the perception of insecurity in conventional employment increases. This hypothesis is based on the previous scenario, while exogenously varying just the value of the parameter $p_{a}$. The results of this exercise are shown in table 3.

Table 3

Changes in allocations, wages, and distribution in response to a sustained increase in the subjective probability of dismissal from conventional employment

\begin{tabular}{|c|c|c|c|c|c|c|c|c|c|c|c|c|c|c|c|}
\hline$p_{a}$ & $p_{b}$ & $w^{a}$ & $w^{b}$ & $e\left(w^{a}, p_{a}\right)$ & $e\left(w^{b}, p_{b}\right)$ & $y_{0}=\hat{y}_{d}$ & $I_{a}$ & $I_{b}$ & $S_{a}$ & IN & $\Pi$ & M.S & Pmec & Pmes & Pmet \\
\hline 0.02 & 0.068 & 1.943 & 1.837 & 0.515 & 0.544 & 315.163 & 61.222 & 10.685 & 19.624 & 334.787 & 196.236 & 138.550 & 5.148 & 1.837 & 4.656 \\
\hline .03 & 0.077 & 918 & 819 & 0.521 & 0.550 & 313.677 & 60.172 & 10.899 & 19.825 & 333.502 & 198.250 & 135.252 & 5.213 & 1.819 & 4.693 \\
\hline .04 & 0.086 & 1.895 & 1.802 & 0.528 & 0.555 & 312.300 & 59.193 & 11.105 & 20.011 & 332.311 & 200.106 & 132.205 & 5.276 & 1.802 & 4.727 \\
\hline 0.05 & 0.095 & 1.874 & 1.785 & 0.534 & 0.560 & 311.010 & 58.271 & 11.305 & 20.183 & 331.193 & 201.834 & 129.359 & 5.337 & 1.785 & 4.760 \\
\hline 0.06 & 0.104 & 1.853 & 1.769 & 0.540 & 0.565 & 309.793 & 57.396 & 11.499 & 20.345 & 330.139 & 203.455 & 126.684 & 5.397 & 1.769 & 4.792 \\
\hline .07 & 0.113 & 1.833 & 1.754 & 0.546 & 0.570 & 308.640 & 56.563 & 11.689 & 20.498 & 329.139 & 204.982 & 124.157 & 5.457 & 1.754 & 4.822 \\
\hline .08 & 0.122 & 1.813 & 1.738 & 0.551 & 0.575 & & 55.766 & & 20.643 & & & & 5.515 & 1.738 & 4.852 \\
\hline 0.09 & 0.131 & 1.795 & 1.723 & 0.557 & 0.580 & 306.500 & 55.002 & 12.058 & 20.780 & 327.279 & 207.797 & 119.482 & 5.573 & 1.723 & 4.880 \\
\hline 0.10 & 0.14 & 1.776 & 1.709 & 0.563 & 0.585 & 305.501 & 54.268 & 12.237 & 20.910 & 326.411 & 209.101 & 117.310 & 5.629 & 1.709 & 4.908 \\
\hline 0.11 & 0.149 & 1.759 & 1.695 & 0.569 & 0.590 & 304 & 53.562 & 12.413 & 21.034 & 325 & 343 & 115.237 & 5.686 & 1.695 & 4.935 \\
\hline .12 & 0.158 & 1.742 & 1.681 & 0.574 & 0.595 & 303.629 & 52.881 & 12.586 & 21.153 & 324.782 & 211.528 & 113.253 & 5.742 & 1.681 & 4.961 \\
\hline 0.13 & 0.167 & 1.725 & 1.667 & 0.580 & 0.600 & 302.748 & 52.224 & 12.757 & 21.266 & 324.015 & 212.662 & 111.352 & 5.797 & 1.667 & 4.986 \\
\hline 0.14 & 0.176 & 1.709 & 1.654 & 0.585 & 0.605 & 301.902 & 51.589 & 12.925 & 21.375 & 323.277 & 213.748 & 109.529 & 5.852 & 1.654 & 5.011 \\
\hline 0.15 & 0.185 & 1.693 & 1.641 & 0.591 & 0.610 & 301.087 & 50.974 & 13.091 & 21.479 & 322.566 & 214.788 & 107.778 & 5.907 & 1.641 & 5.035 \\
\hline 0.20 & 0.23 & 1.620 & 1.579 & 0.617 & 0.633 & 297.343 & 48.156 & 13.890 & 21.935 & 319.278 & 219.353 & 99.925 & 6.175 & 1.579 & 5.146 \\
\hline
\end{tabular}

Source: Prepared by the author.

Note: $p, w, e(w, p)$ and I are the subjective probability of dismissal, the real wage, effort and labour demand, respectively; subscript or superscript "a" refers to the conventional worker and "b" to the self-employed worker; $y_{0}$ is the value of manufacturing output; $S_{a}$ is the value of services; $I N$ is national income; is the profit received by the capitalists for owning the enterprises; M.S. is the wage bill; Pmes, Pmec and Pmet represent average productivity in the service sector, the conventional sector and total, respectively.

As table 3 shows, a sustained increase in the subjective probability of dismissal from conventional employment increases the subjective probability of dismissal among the self-employed. So, when $p_{a}$ is 
$0.02, p_{b}$ is 0.068 , but when $p_{a}$ increases to 0.2 , then $p_{b}$ rises to 0.23 . As the perception of insecurity in conventional employment grows, workers employed by firms see self-employment as a way to avoid unemployment. This would tend to increase the supply of services offered by the self-employed and thus make it harder for all of them to obtain work. Heightened job insecurity for both types of workers forces them to make a greater effort to avoid unemployment. Table 3 shows that as the subjective probability of dismissal increases, the effort made by workers also increases. However, the self-employed always make a greater effort than conventional workers, because their employment is inherently more insecure; that is, $p_{a}<p_{b}$ in all cases.

The additional effort made by both types of worker allows their employers to cut wages, since they no longer need to motivate effort with high pay (see the $w^{a}$ and $w^{b}$ columns of table 3 ). However, as job insecurity increases by more among conventional workers than among the self-employed, the effort made by the former increases faster than that made by the latter, so, conventional worker wages falls faster than those of the self-employed, resulting downward wage convergence, as shown in figure 1.

Figure 1

\section{Downward wage convergence}

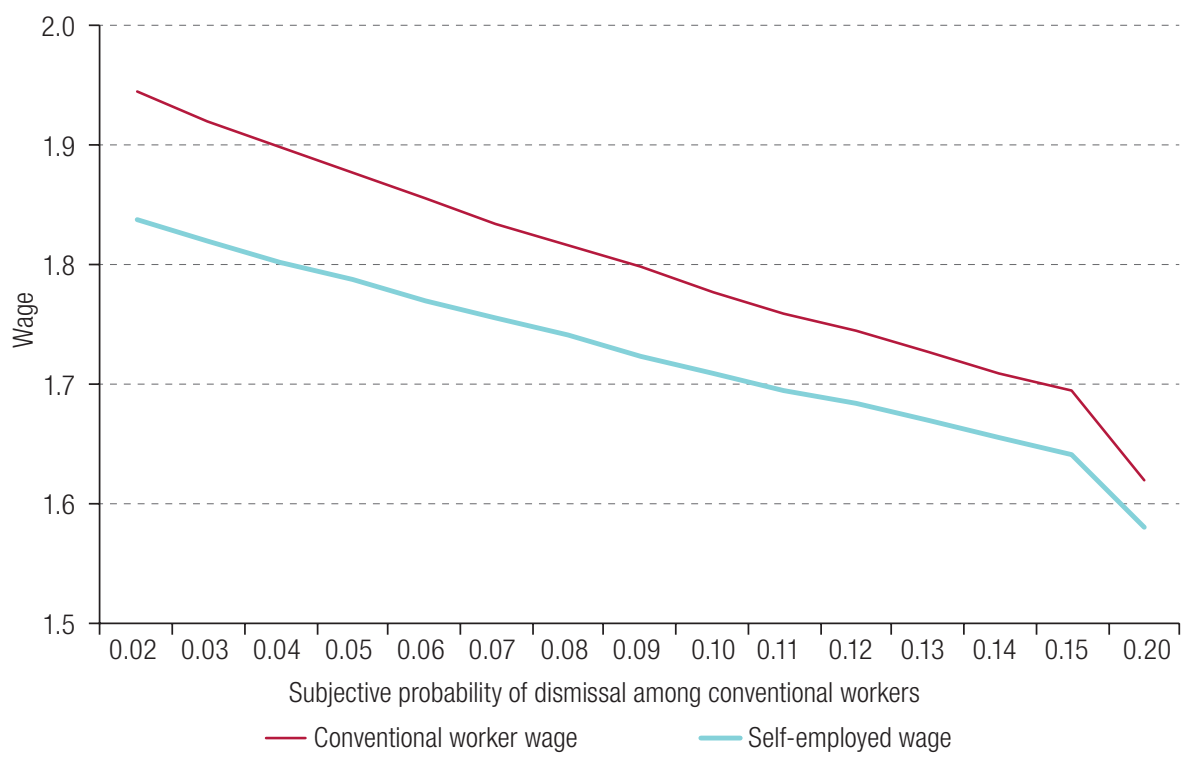

Source:Prepared by the author, based on the wage of the conventional worker and the wage of the self-employed, for different values of the subjective probability of dismissal among conventional workers (data presented in table 3).

Note: In both cases, real wages expressed in terms of units of output.

The fall in the wages of conventional workers results in a reduction in effective demand, so firms cut back on their production and hire less labour. The $y_{0}=\hat{y}_{d}$ column of table 3 shows the fall in effective demand; and, as production is equal to this, the next column $\left(l_{a}\right)$ shows the employment downsizing that firms undertake to match their output to the smaller effective demand.

In table 3, the column labelled shows that firms' profits grow, owing to a widening of the gap between their average productivity and the wage they pay.

Figure 2 shows how the gap between the average productivity and wage indices widens as job insecurity increases. The average productivity of firms grows because workers increase their effort. 


\section{Figure 2}

Average productivity and wage in conventional employment (Index)

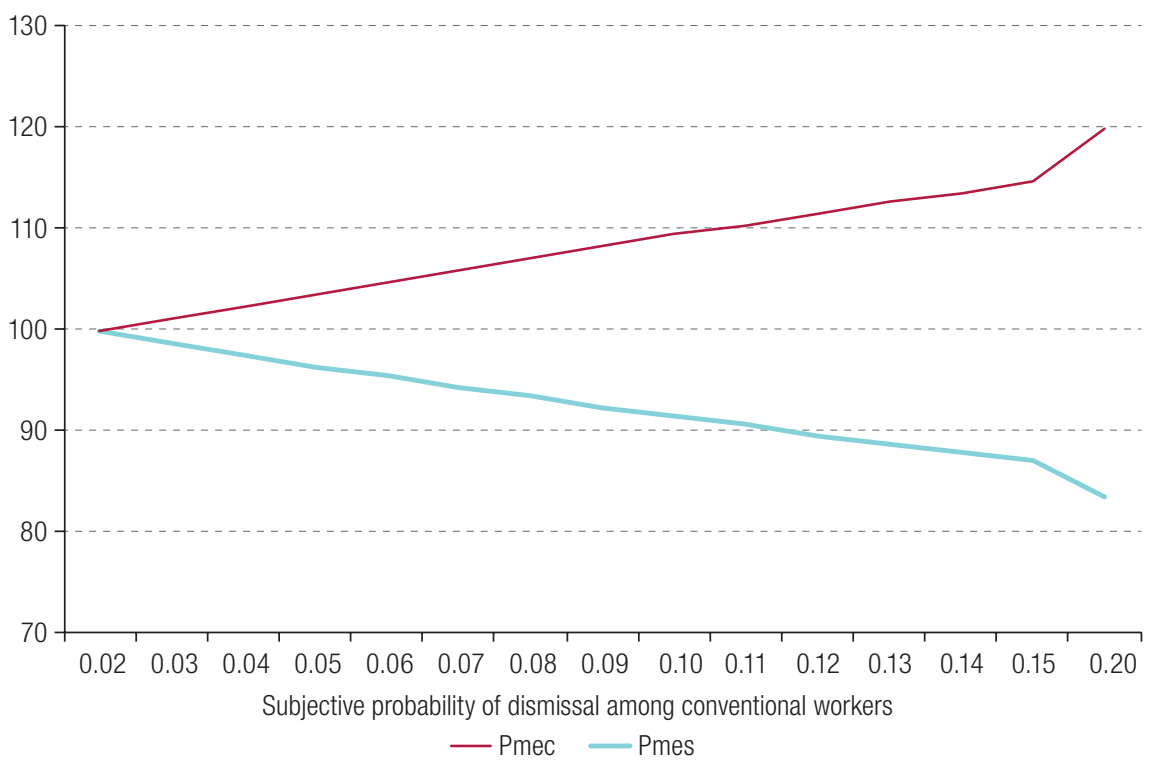

Source: Prepared by the author, based on average productivity data for conventional employment and conventional workers' wages as shown in table 3.

Rising profits and falling wages for self-employed workers cause capitalist consumers to demand more labour. As can be seen in the $l_{b}$ column of table 3 , self-employment increases.

The increased self-employment and reduced conventional employment are consistent with trends in the Mexican economy, where non-precarious jobs have been shrinking and precarious jobs have been expanding.

The generalized reduction in wages, together with the expansion of more precarious employment and the retreat of conventional employment cause the share of the wages in national income to shrink. The $\Pi$ and M.S. columns of table 3 show that the wage share declined, and the profit share grew, as job insecurity increased.

Lastly, it can be seen that the average productivity of the services provided by the self-employed decreased, owing to a reduction in their wages, which devalues the services they supply. In contrast, the productivity of firms increased, owing to the greater effort deployed by their workers. Both types of worker increased their effort, but with opposing effects on their average productivity.

Figure 3 shows how the average productivity of the conventional sector outpaces the average total productivity index, because average productivity among self-employed services falls. 
Figure 3

Average productivity

(Index)

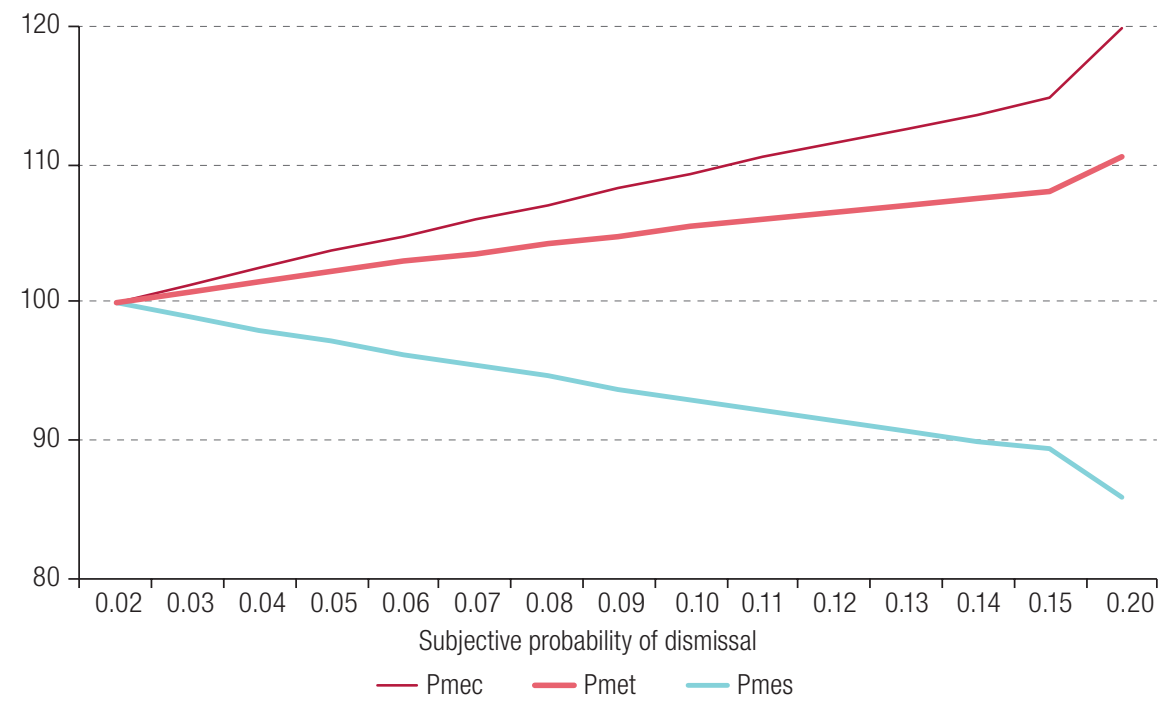

Source: Prepared by the author, based on the data of the average productivities of the service sector, conventional sector and total, as presented in table 3.

One of the main shortcomings of this analytical approach is that it does not incorporate the external sector, so it is effectively a world-economy model. ${ }^{13}$ However, the fact that the decline in the wage share and the increased precariousness of employment are two phenomena that have been observed worldwide, gives the model validity. Nonetheless, as the Mexican economy is one of the most open in the world, it is necessary to sketch conceptually how the results would change in an open-economy model. The increase in the subjective dismissal rate would cause workers to work harder and their wages to fall. Lower wages would make the export sector more competitive and foster its growth. This would allow for profit-driven growth scenarios, provided that the increase in exports outweighed the drop in proletarian consumption. In this scenario, employment could increase.

\section{Conclusions}

The production globalization process that began in the late 1970s and early 1980s fuelled increasing job insecurity. This article has developed an efficiency-wage model in a demand-constrained equilibrium scenario, to show how the increase in job insecurity causes employment to become more precarious and the wage share of income to fall. In addition to arguing that job insecurity and income concentration may have a common, although not unique, cause, the study showed that the process that triggers heightened job insecurity can explain several characteristics of the Mexican economy.

The results of the theoretical model presented here suggest that improving workers' conditions and reversing the process of income concentration require employment policies aimed at reducing job insecurity. 


\section{Bibliography}

Abeles, M., V. Amarante and D. Vega (2014), "The earnings share of total income in Latin America, 1990-2010”, CEPAL Review, No. 114 (LC/G.2629-P), Santiago, Economic Commission for Latin America and the Caribbean (ECLAC).

Alarco, G. (2017), "Ciclos distributivos y crecimiento económico en América Latina, 1950-2014”, Cuadernos de Economía, vol. 36, No. 72.

(2016), "Distribución factorial del ingreso y regímenes de crecimiento en América Latina, 1950-2012", Revista Internacional del Trabajo, vol.135, No. 1.

(2014), "Wage share and economic growth in Latin America, 1950-2011", CEPAL Review, No. 113 (LC/G.2614-P), Santiago, Economic Commission for Latin America and the Caribbean (ECLAC).

Argandoña, A., C. Gámez and F. Mochón (1996), Macroeconomía avanzada, vol. Il, Madrid, McGraw-Hill.

Bhaduri, A. and S. Marglin (1990), "Unemployment and the real wage: the economic basis for contesting political ideologies", Cambridge Journal of Economics, vol. 14, No. 4.

Caraballo, M. Á. (1996), "Salarios, productividad y empleo: la hipótesis de los salarios de eficiencia", Cuaderno de Estudios Empresariales, vol. 6.

Clower, R. W. (1965), "The keynesian counter-revolution: a theoretical appraisal", The Theory of Interest Rate, F. H. Hahn and F. P. Brechling, Londres, Macmillan.

Colmex (2018), Inequalities in Mexico 2018, Mexico City, El Colegio de México.

Corporación Latinobarómetro (2005), Informe Latinobarómetro 2005, Santiago.

Hein, E. (2014), Distribution and Growth after Keynes, Edward Elgar Publishing.

ILO (International Labour Organization) (2018), World Employment and Social Outlook: Trends 2018, Geneva. (2011), World of Work Report 2011: Making Markets Work for Jobs, Geneva.

ILO/OECD (International Labour Organization/ Organisation for Economic Co-operation and Development) (2015), "The labor share in G20 economies", Report Prepared for the G20 Employment Working Group Antaya.

IMF (Internacional Monetary Fund) (2007), World Economic Outlook: Spillovers and Cycles in the Global Economy, Washington, D.C.

INEGI (National Institute of Statistics, Geography and Informatics) (2017), "Encuesta Nacional de Ocupación y Empleo (ENOE)" [online] https://www.inegi.org.mx/programas/enoe/15ymas/.

Kalleberg, A. L. (2009), "Precarious work, insecure workers: employment relations in transition", American Sociological Review, vol. 74, No. 1.

Keynes, J. M. (1936), The General Theory of Employment, Interest and Money, Palgrave Macmillan.

Luyano, C. and J. Herrera (2018), "Distribución funcional del ingreso y régimen de crecimiento en México y España", Cuadernos de Economía, vol. 37, No. 73.

Noriega, F. (2001), Macroeconomía para el desarrollo: Teoría de la Inexistencia del Mercado de Trabajo, Mexico City, McGraw-Hill.

Requiem for the American Dream (2015), Directed by J. P. Scott, K. Nyks, P. Hutchison, Documental, Amazon Prime Video.

Ros, J. (2015), ¿Por qué cae la participación de los salarios en el ingreso total en México?, Economía UNAM, vol. 12, No. 36. (2013), Algunas tesis equivocadas sobre el estancamiento económico de México, Mexico City, El Colegio de México.

Samaniego, N. (2014), "La participación del trabajo en el ingreso nacional: el regreso a un tema olvidado", Economía UNAM, vol. 11, No. 33.

Shapiro, C. and J. Stiglitz (1984), "Equilibrium unemployment as a worker discipline device", The American Economic Review, vol. 74, No. 3.

Solow, R. (1979), "Another possible source of wage stickiness", Journal of macroeconomics, vol. 1, No. 1. Stockhammer, E. (2009), "Determinants of functional income distribution in OCDE countries", IMK Study, vol. 5.

Vázquez, D. A., I. Macias and M. Lawson (2018), "Reward work, not wealth", Oxford, OXFAM International [online] https://www.oxfam.org/en/research/reward-work-not-wealth.

Velázquez, D. and Z. S. Hernández (2018), "Una explicación a la curva de salarios", Cuadernos de Economía, vol. 37, No. 73.

Velázquez, D., J. R. Vargas and Z. S. Hernández (2019), "The effect of public investment on the cycle and economic growth: a simple theoretical model", International Journal of Economics and Financial Issues, vol. 9, No. 1. 


\section{Annex A1}

\section{Producer maximization}

The first-order maxima and minima conditions give:

$$
\begin{gathered}
\frac{d(1+\pi)}{d l_{a}}=\frac{A f_{e\left(w, p_{a}\right) l_{a}}^{\prime} e\left(w, p_{a}\right) w l_{a}-w A f\left(e\left(w, p_{a}\right) l_{a}\right)}{\left(w l_{a}\right)^{2}}=0 \\
\frac{d(1+\pi)}{d w}=\frac{A f_{e\left(w, p_{a}\right) l_{a}}^{\prime} e_{w}^{\prime} w l_{a}-l_{a} A f\left(e\left(w, p_{a}\right) l_{a}\right)}{\left(w l_{a}\right)^{2}}=0
\end{gathered}
$$

Rewriting (A1) gives:

$$
A f_{e}^{\prime}\left(w, p_{a}\right) l_{a} e\left(w, p_{a}\right)=\frac{A f\left(e\left(w, p_{a}\right) l_{a}\right)}{l_{a}}
$$

As $f_{e\left(w, p_{a}\right) l_{a}}^{\prime} e\left(w, p_{a}\right)=f_{l_{a}}^{\prime}$, (A3) can be written as equation (4).

Equation (A2) implies that:

$$
A f_{e}^{\prime}\left(w, p_{a}\right) l_{a} e_{w}^{\prime} w=\frac{A f\left(e\left(w, p_{a}\right) l_{a}\right)}{l_{a}}
$$

Substituting (A3) into (A4) gives equation (3).

\section{Demand-constrained equilibrium}

To solve for equilibrium in the goods market, equation (21) and the respective buying and selling plans are substituted into equations (18), (19) and (20). Hence:

$$
\begin{gathered}
\beta \Pi+\phi \frac{\alpha \tau^{p} w^{a}}{e\left(w^{a}, p_{a}\right)}+(1-\phi) \frac{\alpha \tau^{p} w^{b}}{e\left(w^{b}, p_{b}\right)} \gamma-A e\left(w^{a}, p_{a}\right) l_{a}=0 \\
l_{a}-\phi \frac{\alpha \tau^{p}}{e\left(w^{a}, p_{a}\right)}=0 \\
(1-\beta) \frac{\Pi}{w^{b}}-(1-\phi) \frac{\alpha \tau^{p}}{e\left(w^{b}, p_{b}\right)} \gamma=0
\end{gathered}
$$

Note that wages were determined by equations (3) and (17). On the basis of (A7), $(1-\beta) \Pi=(1-\phi) \frac{\alpha \tau^{p} w^{b}}{e\left(w^{b}, p_{b}\right)} \gamma$. Substituting this expression, the definition of profit and equation (A6) into the goods market equation (A5), gives equation (22); and equation (23) is obtained from (A7) and (A6) and the definition of . Lastly, incorporating the dual decision hypothesis and substituting equations (A6) and (A7) into (21), gives equation (24). 


\section{Increase in profit caused an increase in the subjective probability of unemployment}

To analyse the sign of expression (30), (29) and (27) are substituted into it, to obtain:

$$
\frac{d \Pi}{d p_{a}}=l_{a-1} w_{p_{a}}^{a,}-w_{p_{a}}^{a,} l_{a}-l_{a, p_{a}}^{\prime} w^{a}
$$

Assuming that $l_{a-1}+l_{p_{a}}^{\prime} d p_{a} \approx l_{a}$ and substituting this idea in (A8), gives:

$$
\frac{d \Pi}{d p_{a}}=-w_{p_{a}}^{a,} l_{a, p_{a}}^{\prime} d p_{a}-w^{a} l_{a, p_{a}}^{\prime}
$$

From equation (A9), $\frac{d \Pi}{d p_{a}}>0$ if and only if $\left|w^{a}\right|>\left|w_{p_{a}}^{a,} d p_{a}\right|$, in other words whenever the wage is greater than the absolute amount by which it is reduced. This is true for all $w>0$. 